
\title{
25 Research Square \\ Effects of dehairing treatment on gelatin yield and quality from bovine hides
}

Bimol Roy ( $\nabla$ rimol@ualberta.ca )

University of Alberta https://orcid.org/0000-0002-8919-1346

Chamali Das

University of Alberta

Hui Hong

China Agricultural University

Mirko Betti

University of Alberta

Heather Bruce

University of Alberta

\section{Research Article}

Keywords: Gelatin, Bovine hides, Gel strength, Amino acid, Emulsifying properties

Posted Date: April 28th, 2021

DOI: https://doi.org/10.21203/rs.3.rs-392199/v1

License: (1) This work is licensed under a Creative Commons Attribution 4.0 International License. Read Full License

Version of Record: A version of this preprint was published at Waste and Biomass Valorization on September 22nd, 2021. See the published version at https://doi.org/10.1007/s12649-021-01582-z. 


\section{Abstract}

Purpose Hides are the by product of slaughter houses which are mostly used for leather production. In Canada, the hides are either disposed of with other slaughter waste or sold at a very low price. Dehairing of hides is a prerequisite for either leather or gelatin production from it. Therefore, the effect of hide dehairing method on subsequent gelatin extraction and quality was investigated.

Methods Bovine hides (BH) were dehaired using either $5 \%$ acetic acid (AA), $10 \%$ calcium hydroxide $(\mathrm{CH}), 0.02 \%$ keratinase (KTN), $2.5 \%$ papain (PP), or not at all (control; $C T$ ), with control $B H$ subsequently treated with $5 \% A A$ (CTAA).

Results Mean bovine hide gelatin (BHG) yields (dry basis) were 11.37\%, 54.25\%, 45.07\%, $18.88 \%$ and $55.02 \%$ for $\mathrm{CT}, \mathrm{AA}, \mathrm{CTAA}, \mathrm{CH}$, and $\mathrm{KTN}$, respectively. Gel strength was highest in AA followed by the CTAA, CT and $\mathrm{CH}$ and KTN treatments. The molecular weight (MW) distribution pattern showed that dehairing of $\mathrm{BH}$ with enzymes degraded the collagen extensively, increased proportions of low MW peptides that translated into low gel strength.

Conclusions Acetic acid, which is extensively using in food industry, can be used to dehair $\mathrm{BH}$ as pre-treatment to extracting high quality gelatin.

\section{Statement Of Novelty}

To our knowledge, there is no study has been carried out on dehairing pre-treatment effect on bovine hides for gelatin extraction. The novelty further lies in the application of acetic acid, which is commonly used in the food industry, is an environmentally-friendly chemical for dehairing bovine hides for gelatin extraction and maintaining extracted gelatin quality.

\section{Introduction}

Canada is one of the largest producers of beef in the world. In Canada, the hides of cattle are either disposed of with other slaughter waste or sold at a very low price (\$ $8-10 /$ per hide). Bovine hide $(\mathrm{BH})$ is rich in collagen and is used as a source material in gelatin production. Generally, gelatin is produced by the controlled hydrolysis of its parent molecule collagen, and extraction of gelatin from $\mathrm{BH}$ first requires the hair to be removed. A pre-treatment is always performed on the raw material either with acid or alkali. The pretreatment is useful for removing non-collagenous substances as well as dehairing so as to obtain a high gelatin yield. The pre-treatment process mainly aims to maximize the yield without compromising the desirable properties of the extracted gelatin.

Dehairing and preparation of $\mathrm{BH}$ for gelatin extraction is a chemically-intensive process that involves a lime or lime sulfide bath. For this, hide is generally soaked in $10 \%$ hydrated lime with $1.5 \%$ sodium sulfide at a minimum $\mathrm{pH}$ of 12 for about 40 days. The hides are then acidulated in $0.1 \mathrm{M}$ sulfuric acid at $\mathrm{pH} 1.8$ for $2-3$ days and washed with water [1]. After removal of the hair from the hide, it is ready for gelatin extraction using heat [2]. 
Research has focused on eliminating lime sulfide from the process of dehairing ultimately to create a safe working environment for workers and to remove the risk of environmental pollution. Others have used bacterial keratinases [3] which do not degrade collagen, thereby preserving the length and integrity of the collagen achains [4]. The enzyme papain, which has both collagenolytic and keratinolytic activities, has been shown to have a depilatory effect [5]. Acid pre-treatment is invariably used for raw materials (pig skin, and fish skin and bone) that have fewer inter or intra-molecular collagen cross-links to extract gelatin [6, 7], but it is not usually used in the preparation of raw materials from bovine animals slaughtered close to maturity which have collagen cross-links that are resistant to acid solubilization. For $\mathrm{BH}$, usually an alkali pre-treatment is used to extract gelatin but due to genetic improvement, cattle are now slaughtered at young ages (< 30 months old) and so acid pre-treatment may be a viable option for gelatin extraction.

Shortening the time frame for dehairing of the $\mathrm{BH}$ would also serve to increase product throughput, although it may compromise gelatin yield as lengthy conditioning of $\mathrm{BH}$ with lime sulfide is considered important for maximizing gelatin yield [8]. Gelatin quality may also be negatively impacted by alternative dehairing methods, particularly those that are enzymatic and simultaneously collagenolytic. Consequently, a preliminary, proof of concept study focusing on short-term dehairing and its impact on subsequent gelatin yield and quality was conducted to preliminarily test the efficacy of enzymes for dehairing $\mathrm{BH}$. This preliminary study tested the hypotheses 1) that papain is comparable to keratinases, calcium hydroxide and acetic acid for dehairing of $\mathrm{BH}$ and increasing gelatin yield; 2) that acetic acid is as efficacious as calcium hydroxide for dehairing; and 3) that subsequent extraction with acetic acid following heat extraction of $\mathrm{BH}$ for gelatin increased gelatin yield without reducing gelatin quality.

\section{Materials And Methods}

\section{Collection of bovine hides}

Five fresh $\mathrm{BH}$ from cattle $<30$ month s old were collected from a local abattoir and stored at $-20^{\circ} \mathrm{C}$ until used.

\section{Experimental design and sample handling}

Each frozen $\mathrm{BH}$ was thawed at $4^{\circ} \mathrm{C}$ and divided into a left and right half. The five areas were numbered as $\mathrm{R} 1$, R2, R3, R4 and R5 from cranial to caudal (Fig. 1). For randomization, R1, R2, R3, R4 and R5 locations from the five different $\mathrm{BH}$ were randomly assigned to different treatments (Table 1) for dehairing and gelatin extraction in a manner balanced for hide area. The selected parts of $\mathrm{BH}$ were soaked in and washed with water to remove blood and extraneous materials. The flesh side of the hide was scrubbed to remove fat and meat and cut into squares of approximately $5 \times 5 \mathrm{~cm}^{2}$.

\section{Dehairing treatments}

$\mathrm{BH}$ pieces were incubated in the randomly assigned dehairing solvents at a ratio of 1:10 (w/v) with vigorous stirring for $24 \mathrm{~h}$ at room temperature $\left(23^{\circ} \mathrm{C}\right)$ to maintain same condition for all treatments. The $\mathrm{BH}$ pieces were incubated in deionized (DI) water (negative control) (CT), 10\% calcium hydroxide (pH 12-13) (positive control) $(\mathrm{CH}), 5 \%$ acetic acid (AA), $0.02 \%$ aqueous keratinase enzyme (from Bacillus licheniformis, Wako Chemicals Inc) ( $\mathrm{pH} 8-9)(\mathrm{KTN})$, and 2.5\% (w/v) aqueous papain enzyme (papain from papaya latex, Sigma) (pH 8-9) 
(PP). A sixth treatment evolved from the $\mathrm{CT}$ as the $\mathrm{BH}$ of the $\mathrm{CT}$ group after gelatin extraction was subsequently incubated with $5 \%$ acetic acid and then used for gelatin extraction (CTAA).

After dehairing treatment, the $\mathrm{BH}$ pieces were washed with DI water to remove reactants and both sides of the hide were scrubbed to remove hair and any residual flesh or fat. Fifteen (15) fields of $1.1 \times 1.4 \mathrm{~cm}^{2}$ on the hide surface of each $\mathrm{BH}$ piece were randomly photographed and total hairs were counted for each field. Means of the 15 fields were used for statistical analysis. The $\mathrm{BH}$ pieces were then stored at $-20^{\circ} \mathrm{C}$ until gelatin extraction.

\section{Gelatin extraction}

The frozen, post-treatment $\mathrm{BH}$ pieces were thawed at $4^{\circ} \mathrm{C}$. The $\mathrm{BH}$ pieces were immersed in $\mathrm{DI}$ water at a ratio of $1: 5(\mathrm{w} / \mathrm{v})$ and heated at $80^{\circ} \mathrm{C}$ for $4 \mathrm{~h}$. The soluble fraction (extracted gelatin) was filtered through 4 folds of cheesecloth, cooled in ice water, dialyzed against DI water until the conductivity was lower than $50 \mu$ Siemens, frozen and freeze-dried.

The yield of gelatin was calculated as follows:

Gelatin yield $(\%)=$ Weight of freeze-dried gelatin $(\mathrm{g}) \quad \times \quad 100$

Wet tissue basis

Weight of wet hides used for gelatin extraction $(\mathrm{g})$

Gelatin yield $=$ Weight of freeze-dried gelatin $(\mathrm{g})$

$\times \quad 100$

(\%)

Dry tissue

basis

Weight of wet hides used for gelatin extraction $(\mathrm{g}) \times$ dry matter in wet hides (\%)

\section{Proximate composition}

The proximate composition of $\mathrm{BH}$ and bovine hide gelatin $(\mathrm{BHG})$ were measured by following official methods of analysis AOAC (moisture; 950.46, fat; 960.39 and ash; 920.153) [9]. Crude protein was determined with a TruSpec carbon/nitrogen determinator (Leco Corp., St. Joseph, MI). Conversion factors of 6.25 and 5.4 [10] were used to calculate protein in $\mathrm{BH}$ and $\mathrm{BHG}$, respectively. All measurement was done in duplicate and means were used for statistical analysis.

\section{Gelatin solution characteristics}

The $\mathrm{pH}$ was measured according to the British Standard Institution method [11] with a glass electrode (Orion 2 $\mathrm{Star}^{\mathrm{TM}}$ and Star Plus Meter) in a $2 \%$ BHG solution. The $\mathrm{pH}$ meter was calibrated with standard commercial buffers ( $\mathrm{pH} 4.0,7.0$ and 10.0). The percent transmittance was measured in a $2 \%$ BHG solution. For this, the

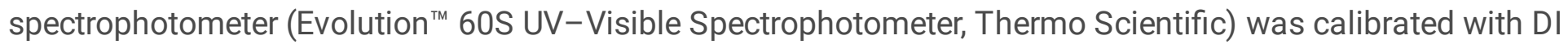
water as a blank representing $100 \%$ transmittance and was measured at $620 \mathrm{~nm}$. The isoelectric point $\left(P^{l}\right)$ of 
the $2 \%$ BHG solution was determined by measuring the percent transmittance at different pH (from 2 to 10 ) at $660 \mathrm{~nm}$ by following the method of Roy et al. [12].

\section{Dynamic viscoelastic properties}

Dynamic viscoelastic properties of $6.67 \%$ BHG gel were measured using a Physica MCR 301 rheometer (Anton Paar $\mathrm{GmbH}$ ) following the method of Roy et al. [12]. Briefly, the linear viscoelastic range (LVR) of the gel was tested by the amplitude sweep test with an increasing oscillatory strain (from 0.1 to $20 \%$ ) at a constant frequency $(1 \mathrm{hertz})$ and temperature $\left(10^{\circ} \mathrm{C}\right)$. The frequency sweep test was conducted at $10^{\circ} \mathrm{C}$, employing a constant strain of $5 \%$ and varying the frequency from 0.2 to 100 hertz within the identified LVR region. The viscoelastic properties of BHG gel were measured at a constant strain of $5 \%$ and a constant frequency of 1 hertz (at the LVR) under oscillation ( $25 \mathrm{~mm}$ parallel plates with a $1 \mathrm{~mm}$ gap between the plates) and the temperature was maintained from 45 to $10^{\circ} \mathrm{C}$ with a heating/cooling rate of $2^{\circ} \mathrm{C} / \mathrm{min}$. Gelling and melting point of the gel was determined by the sharp increase of storage modulus (G区) during cooling and the sharp decrease during heating, respectively.

\section{Color of gelatin gel}

Gel color was measured using the $6.67 \%$ BHG gel with a Konica Minolta Chroma Meter CR-410 colorimeter and expressed as lightness $\left(L^{*}\right)$, redness $\left(a^{*}\right)$, yellowness $\left(b^{*}\right)$. The colorimeter was calibrated with the standard white calibration plate provided by the manufacturer prior to measurement and the D65 illuminant was used. Color of gelatin was measured in triplicate and means were used for statistical analysis.

\section{Gel strength}

The gel strength of the $6.67 \%$ BHG solution was determined by following the British Standard Institution method [11]. Freeze-dried gelatin (7.50g) was allowed to swell in DI water (105mL) for 3h in a standard Bloom jar (150mL, Schott, Mainz, Germany) and then dissolved completely by heating at $45^{\circ} \mathrm{C}$ for $15 \mathrm{~min}$. It was then cooled to room temperature, matured at $10^{\circ} \mathrm{C}$ for $18 \mathrm{~h}$ and then gel strength was determined using a texture analyzer (TA-XT2, Stable Micro Systems, Surrey, UK) equipped with $2 \mathrm{kN}$ load cell and a $1.27 \mathrm{~cm}$ diameter flat faced cylindrical Teflon plunger. The gel strength was recorded in gram when the plunger penetrated $4 \mathrm{~mm}$ into the gel at a speed of $0.5 \mathrm{~mm} / \mathrm{sec}$. Gel strength was measured in triplicate and means were used for statistical analysis.

\section{Gelatin thermal properties}

The thermal properties of BHG were measured with a multi-cell differential scanning calorimeter (TA Instruments, New Castle, Delaware) following the method of Roy et al. [12]. The matured BHG after gel strength measurement was weighed (about 500mg) into an ampoule, capped and were run at a heating rate of $1^{\circ} \mathrm{C} / \mathrm{min}$ from 20 to $60^{\circ} \mathrm{C}$. An empty ampoule was used as reference. The helix-coil transition temperature was calculated from the endothermic peak and the enthalpy change was measured by integrating the area under the peak. Samples were measured in triplicate and means were used for statistical analysis.

\section{Foaming properties}


Gelatin solutions $(0.5,1$ and $2 \%)$ were prepared and from each concentration $25 \mathrm{~mL}$ were placed in a tube, homogenized (1 min at $20000 \mathrm{rpm}$ ) with an Ultra-Turrax Ika T-18 homogenizer to incorporate air and increase the volume. The total volume was measured at 0,30 and 60 min of homogenization and the foam expansion (FE) and foam stability (FS) were calculated by the following equations:

\begin{tabular}{|c|c|c|c|c|}
\hline $\mathrm{FE}(\%)=$ & $\left(\mathrm{V}_{\mathrm{T}}-\mathrm{V}_{0}\right)$ & $\times 100$ & $\mathrm{FS}(\%)=$ & $\left(V_{t}-V_{0}\right)$ \\
\hline & $\mathrm{V}_{0}$ & & & $\mathrm{~V}_{0}$ \\
\hline
\end{tabular}

Where, $\mathrm{V}_{\mathrm{T}}=$ total volume after homogenization $(\mathrm{mL}) ; \mathrm{V}_{0}=$ volume before homogenization; and $\mathrm{V}_{\mathrm{t}}=$ total volume after storage at room temperature for 30 and $60 \mathrm{~min}$.

\section{Emulsifying properties}

Gelatin solutions $(0.5,1$ and $2 \%)$ were prepared with DI water and from each concentration, $8 \mathrm{~mL}$ gelatin solution were added with $2 \mathrm{~mL}$ of edible sunflower oil and homogenized for $1 \mathrm{~min}$ at $24000 \mathrm{rpm}$ at room temperature. Then, $50 \mu \mathrm{L}$ of homogenized emulsion were taken from the bottom of the tube at 0 and 30 min after emulsion formation, added to $5 \mathrm{~mL}$ of $0.1 \%$ sodium dodecyl sulphate (SDS) solution and mixed thoroughly by vortex for $10 \mathrm{sec}$. The absorbance was measured at $500 \mathrm{~nm}$ and $0.1 \%$ SDS solution was used as the blank at $0\left(A_{0}\right)$ and at 30 min $\left(A_{30}\right)$ after homogenization. The emulsion activity index (EAl) and emulsion stability index (ESI) of BHG were determined by the following equations:

$$
\begin{array}{ll}
\operatorname{EAl}\left(\mathrm{m}^{2} / \mathrm{g}\right)= & \frac{2 \times 2.303 \times \mathrm{A}_{500} \times \mathrm{DF}}{\mathrm{C} \times \varphi \times 10^{4}}
\end{array}
$$

Where, $A_{500}=$ absorbance at 500nm, DF= dilution factor $(100), C=$ protein concentration $(\mathrm{g} / \mathrm{mL})$ before emulsification, $\varphi=$ oil volume fraction ( $v / v)$ of the emulsion (i. e., the volume of emulsion droplets divided by the total volume of emulsion, $\varphi=0.2$ ), and $A_{30}$ and $A_{0}$ represent the absorbance after $30 \mathrm{~min}$ and at time zero, respectively, at 500nm after emulsification, $\Delta A=A_{30}-A_{0}$ and $\Delta T=30 \mathrm{~min}$.

\section{Water holding capacity (WHC) and fat binding capacity (FBC)}

Freeze-dried BHG was dissolved in DI water or sunflower oil $(10 \mathrm{mg} / \mathrm{mL})$, and allowed to stand for $1 \mathrm{~h}$ with stirring every $15 \mathrm{~min}$. Then, the supernatant was decanted and the tubes were inverted at $45^{\circ}$ for 30 min to drain the water or oil completely. The WHC and FBC were calculated using the following equation:

WHC or FBC $(\%)=\quad$ Weight of the contents in the tube after draining $(\mathrm{g}) \quad \times 100$

Weight of the freeze-dried gelatin $(\mathrm{g})$ 


\section{Molecular weight distribution}

Molecular weight (MW) distribution of dehaired BH and BHG was performed using sodium dodecyl sulfate polyacrylamide gel electrophoresis following the Laemmli [13] method. Dehaired BH and BHG were diluted with sample buffer $(5 \mathrm{mg} / \mathrm{mL})$, vortex, heated at $95^{\circ} \mathrm{C}$ for $5 \mathrm{~min}$ and centrifuged at $5000 \mathrm{~g}$ for $5 \mathrm{~min}$. Ten $\mu \mathrm{L}$ of each sample and MW marker standard (Bio-Rad Laboratories Inc.) were loaded on a precast 4 to $20 \%$ gradient gel (Bio-Rad Laboratories Inc.). The samples were run at a constant voltage of $170 \mathrm{~V}$ on a Power Pack Basic ${ }^{\mathrm{TM}}$ electrophoresis apparatus (BioRad Laboratories Inc.). After electrophoresis, the bands in the gel were stained with Coomassie Brilliant Blue R-250 and de-stained with a mixture of DI water, methanol and acetic acid at a ratio of 50:40:10.

\section{Amino acid composition}

The amino acid composition of BHG was determined using the method of Roy et al. [12]. Gelatin solution (1 $\mathrm{mg} / \mathrm{mL}$ ) was hydrolysed at $160^{\circ} \mathrm{C}$ for $1 \mathrm{~h}$ in $6 \mathrm{M} \mathrm{HCl}$ containing $0.1 \%$ phenol. An AccQ-Tag Ultra Derivatization Kit (Waters, Milford, MA) was used to label the hydrolysates. Hydrolysates were analyzed by high performance liquid chromatography (HPLC) (Agilent 1200 Series) using an AccQ-Tag C18 column (3.9×150mm, Waters) at $254 \mathrm{~nm}$ for detection. Norleucine (Sigma-Aldrich Inc) was used as an internal standard and hydroxyproline from a calorimetric assay standard kit (BioVision Incorporated) as an external standard.

\section{Fourier transform infrared spectroscopy (FTIR)}

Freeze-dried BHG were analyzed using FTIR with a Nicolet ${ }^{\text {TM }}$ iS50 FTIR Spectrometer (Thermo Fisher Scientific) equipped with an attenuated total reflection accessory. The spectra were recorded at a resolution of $4 \mathrm{~cm}^{-1}$ and measured from 400 to $4000 \mathrm{~cm}^{-1}$ against a background spectrum performed with a clean empty cell. The automatic signals were collected with accumulation of 32 scans per spectrum. Spectral data were analysed with the data collection software program (OMNIC 7.3, Thermo Electron Corporation). Samples were measured in duplicate and means were used for statistical analysis.

\section{Statistical analysis}

One-way analysis of variance was performed to compare the effect of dehairing treatment on the efficacy of dehairing, the recovery of gelatin and the various quality measurements performed on BHG. Data were analyzed with the Statistical Analysis Software (SAS Institute Inc., Cary, NC). Tukey's post-hoc test was used when the differences between means were found significant $(P<0.05)$.

\section{Results And Discussion}

\section{Dehairing efficacy}

All treatments showed evidence of the ability to dehair the $\mathrm{BH}$ in the allotted $24 \mathrm{~h}$ time frame (Fig. 2). The number of hairs on $\mathrm{BH}$ from $\mathrm{CT}$ and CTAA were too numerous to count; therefore, these treatments were not included in the statistical analysis comparing number of hairs remaining after dehairing. Within those treatments where the numbers of hairs were able to be quantified, there was no significant difference due to 
treatment (Table 1, Fig. 2), and so the hypothesis was that papain is comparable to keratinases for the dehairing of $\mathrm{BH}$ was accepted. We also accepted the hypothesis that acetic acid is as efficacious as calcium hydroxide for dehairing $\mathrm{BH}$ because the number of hairs remaining after treatment were not different $(P>0.05)$ (Table 1). Acetic acid provides a more environmentally-friendly alternative to the lime-sulfide baths traditionally used to dehair $\mathrm{BH}[14]$.

\section{Gelatin yield and physical properties}

Acetic acid at the concentration used in this study (5\%) produced gelatin yields on a wet tissue basis that were lower than that of KTN, but greater than that of $\mathrm{CH}$ and the control (DI water) (Table 2). On a dry tissue basis, KTN, AA and CTAA showed higher yields than $\mathrm{CH}$ and $\mathrm{CT}$, indicating that the use of AA or KTN improved gelatin yield over the conventional $\mathrm{CH}$ in the experimental time frame of $24 \mathrm{~h}$, a time frame much shorter than that used by the gelatin industry. Increased yield of gelatin is an indication of increased collagen denaturation [15] and these results agreed with those of others who have shown that the use of enzymes can increase gelatin yield, but this is the first report of acetic acid doing so. Acetic acid swells collagen, making it easier to be denatured by heat [16] or attacked by enzymes such as pepsin [17].

Regardless of differences in protein and crude fat (Table 2), all the gelatins produced in the treatments with the exception of that from the papain treatment were comparable to that of commercial gelatin $(90.22 \%$ crude protein, $8.52 \%$ moisture, $0.21 \%$ crude fat and $0.29 \%$ ash) [18] which agrees with the present results. As expected, the $\mathrm{pH}$ values of the BHG from the AA and CTAA treatments were the lowest, while that from the $\mathrm{CH}$ treatment had the highest pH value, followed by the KTN and CT treatments (Table 2). According to GMIA [19], $\mathrm{BHG}$ of CT and CTAA are type $\mathrm{A}(\mathrm{pH} 7-9)$, while those from $\mathrm{CH}$ and $\mathrm{KTN}$ treatments are type $\mathrm{B}(\mathrm{pH} 4.8-5.4)$. Both the $\mathrm{pH}$ and the $\mathrm{Pl}^{\mathrm{I}}$ (Fig. 3) of gelatin depend on the type, strength and $\mathrm{pH}$ of the chemicals used in pretreatment processes $[19,20,21]$. In bovine heart gelatin, $\mathrm{pH}$ values near the $\mathrm{P}^{\prime}$ resulted in a lower gel strength [12]. At the $P$, protein molecules in gelatin solutions form aggregates, reducing the amount of water that can interact with the protein molecules [22] which reduces gel strength.

Despite the efficacy of papain with regard to dehairing of $\mathrm{BH}$, papain produced an inferior gelatin product even in the limited time that the $\mathrm{BH}$ was exposed to it. The gelatin from the PP treatment was unable to form a gel at the standard Bloom strength test concentration of $6.67 \%$, and so it was not further characterized in this study. Dehairing with papain and keratinase appeared to promote cleavage of a-chains (a1 and a2), increasing the amount of low MW fragments following gelatin extraction (Fig. 4). Gelatin from BH treated with papain was extremely degraded and exhibited very low MW peptides $(<25 \mathrm{kD})$. Gelatins with low MW peptides are usually unable to form a gel [23] because of the restricted electrostatic junctions [24]. Gelatins extracted using enzymes have showed lower gel strength than gelatins extracted using only heat [25] and this corroborates with the results of the present study. Dehairing with AA also produced gel with greater strength than that of $\mathrm{CH}$, with gel strength highest in AA and CTAA gelatin and lowest in KTN gelatin (Table 2). The BHG of $C T, A A$ and CTAA contained high MW components ( $a, \beta$ and $\gamma$-chains) as the major protein constituents with fewer low MW peptides than $\mathrm{CH}$ and KTN gelatin, and this was associated with increased gel strength (Fig. 4). This result substantiated that gelatin with an increased proportion of high MW components ( $\alpha, \beta$ and $\mathrm{Y}$-chains) has increased gel strength [26] because low MW peptides cannot form the lengthy junction zones needed to develop a strong protein network [27]. Methionine and phenylalanine proportions were reduced only 
in the gelatin extracted using acid or enzymatic methods, suggesting that erosion of the collagen a-chains was more extensive than in the $\mathrm{CT}$ or $\mathrm{CH}$ treatments, but it did not appear to affect gel strength of $\mathrm{AA} \mathrm{BH}$ (Table 3). Gel strength is considered the utmost quality parameter of gelatin [23] and gelatin that contained increased hydroxyproline also shows increased gel strength [26] but in this study there was no difference in hydroxyproline content between treatment groups. Hydroxyproline in gelatin helps to form three-dimensional hydrogen bonds between water molecules and free hydroxyl groups of amino acids, which affords the strength and rigidity to the gelatin gel [28], and directly hydrogen bonds to the carbonyl groups [15]. The stability of gelatin is proportional to the glycine content just as it is for the parent molecule collagen [29], but in the present study, increased glycine proportion was not related to gel strength.

The spectral differences of the BHG (Fig. 7 and Table 6) may be related to the differences in their MW distribution [29]. The lower wavelength range of amide A peak in the present study might be due to fewer exposed amino groups in extracted gelatin involved in hydrogen bonding [30]. Gelatin extracted after alkali and enzymes treatment (KTN and $\mathrm{CH}$ ) showed the amide B peak at a lower wavenumber range (Table 6) compared to the $\mathrm{CT}$, AA and CTAA gelatins, which suggested that the $-\mathrm{NH}_{3}$ group interacts between peptide chains [31]. These results support the conclusion that the dehairing treatment affected the secondary structure of $\mathrm{BHG}$.

Acetic acid dehairing produced gelatin with quality and properties comparable or superior to that of the $\mathrm{CH}$ treatment. Gelatin from the AA treatment exhibited greater transmittance (clarity) and $L$ * values than that of the KTN and CT treatments, which were comparable to those achieved using $\mathrm{CH}$ and indicated that gelatins from AA, CTAA and $\mathrm{CH}$-treated $\mathrm{BH}$ were paler than that of other treatments (Table 2). Generally, color of gelatin has no influence on functional properties but a light color is preferred as it allows gelatin to be incorporated into foods without compromising the original color of the product [10]. The transmittance of gelatin is very important in food applications because the gelatin with the highest transmittance has no negative effect on the color or opacity of the final product [32]. Low transmittance of gelatin is mainly caused by inorganic substances, proteins, mucopolysaccharides and other contaminants [33] and these contaminants can be removed by filtration [27]. These results indicated that dehairing of $\mathrm{BH}$ with acetic acid, calcium hydroxide, or keratinase assisted with the removal of contaminants before gelatin extraction, increasing the transmittance of the gelatin.

Rheological properties also indicated that AA gelatin was comparable or superior to that of the $\mathrm{CH}$ dehairing treatment. Although gelling and melting temperature, storage (G区) and loss modulus (G区, not shown) of BHG (Fig. 5) showed no differences due to dehairing treatments, the elastic response (measured by G $\nabla$ ) was highest in gelatin from AA followed by CTAA, CH, CT and lowest in KTN (Fig. 6). Also, the thermal denaturation properties of the BHG from AA and CTAA treatments were comparable to or showed more stability than that of $\mathrm{BHG}$ from the $\mathrm{CH}$ treatment (Table 4). The onset of denaturation temperature of the BHG was higher in CT than in $\mathrm{CH}$ and $\mathrm{KTN}$ treatments. The enthalpy of BHG was higher in AA than in $\mathrm{CH}$ and $\mathrm{KTN}$ treatments. Compared with CT, gelatin from AA and CTAA treatments showed no differences in enthalpy and thermal denaturation temperature. This indicated that dehairing with acetic acid (AA and CTAA) cleaved the intramolecular cross-links of the parent molecule collagen with limited damage to the integrity of the triple helix portion of the collagen molecule as reflected by the MW distribution (Fig. 4). On the other hand, dehairing with $\mathrm{CH}$ and $\mathrm{KTN}$ damaged the integrity of the triple helix portion of the collagen a-chains as evidenced by the 
increased proportion of low MW peptides (Fig. 4), reduced enthalpy and thermal denaturation temperature. The peak denaturation temperature of BHG in different treatments did not differ and was not expected to as the proline and hydroxyproline content also did not differ which agreed with the report of Kittiphattanabawon et al. [24].

The foam expansion (FE) and foam stability (FS) did not differ due to treatments (Table 5), and were therefore not affected by MW distribution (Fig. 4). Foaming properties of gelatin are important when it is to be incorporated into foods like marshmallows [34]. Ahmed and Benjakul [35] reported that gelatin with low MW peptides showed poor foaming properties because they are unable to form a well-ordered film at the airwater interface. Gelatins derived from BH dehaired using acetic acid (AA and CTAA) had the highest ESI at 2 and $1 \%$, concentrations, respectively, although differences between the treatments were limited (Table 5). The EAI of BHG at $0.5 \%$ and $1 \%$ concentrations was lowest in CT compared with other treatments.

The AA showed the highest WHC followed by the CTAA and CT, with the lowest being from the CH and KTN (Table 5). The WHC of gelatin is a desirable trait in some food items (sausages, custards and dough) because these items absorb water without dissolving proteins, and by that mechanism attain body thickening and viscosity properties [36]. The BHG regardless of treatment showed a high value of WHC, as one gram of dry gelatin was capable of retaining 4.51-34.39 g of water (Table 5) and agreed with the results of Wasswa et al. [37]. The primary function of a hydrocolloid is to retain water and the high WHC of BHG suggests that it has a large number of pores in its structure [38]. The CT showed the highest $\mathrm{FBC}$ and this difference may be due this gelatin having the highest leucine content (Table 5). According to Ninan et al. [39], FBC increased with the increased degree of exposure of the hydrophobic residues and the increased amount of leucine, isoleucine, tyrosine and valine.

\section{Conclusions}

$\mathrm{BH}$ was dehaired successfully by all treatments, but gelatin quality was profoundly lowered when dehairing involved enzymes, with low gel strength observed when $\mathrm{BH}$ was dehaired with keratinase and papain.

Dehairing with KTN increased gelatin yield, but the use of $5 \%$ acetic acid for dehairing yielded quantities of gelatin comparable to that of $\mathrm{CH}$, which had an acceptable range of gel strength and quality and gel strength that exceeded that of the conventional standard $\mathrm{CH}$. The results of this study should be viewed with caution, as conditions for dehairing were not optimized and did not reflect standard industry practices, but acetic acid, which is already used in the food industry, is a promising chemical to dehair $\mathrm{BH}$ and increase gelatin yield from the highly cross-linked collagen of $\mathrm{BH}$.

\section{Declarations}

\section{Acknowledgements}

The authors would like to thanks Alberta Livestock and Meat Agency (Grant No. 2011R030R) for financial support.

\section{Conflict of interests}


There are no conflicts of interest to report

\section{Availability of data and material}

Data will be available on request at anytime

\section{Author contributions}

Bimol C. Roy and Chamali Das jointly performed assays and laboratory work, and Bimol C. Roy wrote the manuscript. Heather L. Bruce performed experimental design, statistical analysis, and manuscript review and editing. Hui Hong assisted with FTIR data analyses and manuscript editing and review. Mirko Betti assisted with the Rheometer run, editing and review of the manuscript.

\section{Ethics approval}

Not applicable

\section{Consent to participate}

All authors provided consent for their participation

\section{Consent for publication}

All authors provided their consent for publication

\section{References}

1. Saravanabhavan, S., Rao, J.R., Nair, B.U., Ramasami, T.: An eco-efficient rationalized leather process. J. Chem. Technol. Biotechnol. 82, 971-984 (2007). https://doi.org/10.1002/jctb.1727

2. Barbooti, M.M., Raouf, S.R., Al-Hamada, F.H.K.: Optimization of production of food grade gelatin from bovine hide wastes. Eng. Technol. 26, 240-253 (2008)

3. Riffel, A., Ortolan, S., Brandelli, A.: De-hairing activity of extracellular proteases produced by keratinolytic bacteria. J. Chem. Technol. Biotechnol. 78, 855-859 (2003). https://doi.org/10.1002/jctb.828

4. De Souza, F.R., Gutterres, M.: Application of enzymes in leather processing: a comparison between chemical and coenzymatic processes. Braz. J. Chem. Eng. 29, 473-481 (2012). https://doi.org/10.1590/S0104-66322012000300004

5. Traversa, E., Machado-Santelli, G.M., Velasco, M.V.R.: Histological evaluation of hair follicle due to papain's depilatory effect. Int. J. Pharm. 335, 163-166 (2007). https://doi.org/10.1016/j.ijpharm.2007.01.020

6. Sompie, M., Surtijono, S.E., Pontoh, J.H.W., Lontaan, N.N.: The effects of acetic acid concentration and extraction temperature on physical and chemical properties of pig skin gelatin. Procedia Food Sci. 3, 383388 (2015). https://doi.org/10.1016/j.profoo.2015.01.042

7. Binsi, P.K., Shamasundar, B.A., Dileep, A.O., Badii, F., Howell, N.K.: Rheological and functional properties of gelatin from the skin of Big eye snapper (Priacanthus hamrur) fish: influence of gelatin on the gel-forming 
ability of fish mince. Food Hydrocoll. 23, 132-145 (2009). https://doi.org/10.1016/j.foodhyd.2007.12.004

8. Schrieber, R., Gareis, H.: From collagen to gelatin. In: Gelatine handbook: Theory and industrial practice, pp. 82-114. Weinheim, Wiley-VCH (2007)

9. AOAC: Official method of analysis of association of chemistry. The Association of Official Analytical Chemists, Washington, D. C. (2000)

10. Shyni, K., Hema, G.S., Ninan, G., Mathew, S., Joshy, C.G., Lakshmanan, P.T.: Isolation and characterization of gelatin from the skins of skipjack tuna (Katsuwonus pelamis), dog shark (Scoliodon sorrakowah), and rohu (Labeo rohita). Food Hydrocoll. 39, 68-76 (2014). https://doi.org/10.1016/j.foodhyd.2013.12.008

11. British Standards Institution: Methods for sampling and testing gelatin (physical and chemical methods). BSI, London (1975)

12. Roy, B.C., Das, C., Hong, H., Betti, M., Bruce, H.L.: Extraction and characterization of gelatin from bovine heart. Food Biosci. 20, 116-124 (2017). https://doi.org/10.1016/j.fbio.2017.09.004

13. Laemmli, U.K.: Cleavage of structural proteins during the assembly of the head of bacteriophage T4. Nature. 227, 680-685 (1970). https://doi.org/10.1038/227680a0

14. Senthilvelan, T., Kanagaraj, J., Mandal, A.B.: Application of enzymes for dehairing of skins: cleaner leather processing. Clean Technol. Environ. Policy. 14, 889-897 (2012). https://doi.org/10.1007/s10098-0120458-5

15. Wong, D.W.S.: Mechanism and theory in food chemistry. Van Nostrand Reinhold, New York (1989)

16. Liu, D.C., Lin, Y.K., Chen, M.T.: Optimum condition of extracting collagen from chicken feet and its characteristics. Asian-Australas. J. Anim. Sci. 14, 1638-1644 (2001).

https://doi.org/10.5713/ajas.2001.1638

17. Nalinanon, S., Benjakul, S., Visessanguan, W., Kishimura, H.: Improvement of gelatin extraction from bigeye snapper skin using pepsin-aided process in combination with protease inhibitor. Food Hydrocoll. 22, 615-622 (2008). https://doi.org/10.1016/j.foodhyd.2007.01.012

18. Balti, R., Jridi, M., Sila, A., Souissi, N., Nedjar-Arroume, N., Guillochon, D., Nasri, M.: Extraction and functional properties of gelatin from the skin of cuttlefish (Sepia officinalis) using smooth hound crude acid protease-aided process. Food Hydrocoll. 25, 943-950 (2011).

https://doi.org/10.1016/j.foodhyd.2010.09.005

19. GMIA. Gelatin Handbook. Gelatin Manufacturers Institute of America. New York: (2012). http://www.gelatin-gmia.com/ html/qanda.html [retrieved: 22.09.2012]

20. Jamilah, B., Harvinder, K.G.: Properties of gelatins from skins of fish-black tilapia (Oreochromis mossambicus) and red tilapia (Oreochromis nilotica). Food Chem. 77, 81-84 (2002).

https://doi.org/10.1016/S0308-8146(01)00328-4

21. Cole, C.G.B., Gelatin, Encyclopedia of Food Science and Technology, Frederick, J., Francis (Eds) (pp. pp. 1183-1188). John Wiley \& Sons, New York, (2000)

22. Hafidz, R.M., Yaakob, R.N., Amin, C.M., Noorfaizan, I.: A.: Chemical and functional properties of bovine and porcine skin gelatin. Int. Food Res. J. 18, 813-817 (2011)

23. Boran, G., Regenstein, J.M.: Optimization of gelatin extraction from silver carp skin. J. Food Sci. 74, E432E441 (2009). https://doi.org/10.1111/j.1750-3841.2009.01328.x 
24. Kittiphattanabawon, P., Benjakul, S., Visessanguan, W., Shahidi, F.: Comparative study on characteristics of gelatin from the skins of brown banded bamboo shark and blacktip shark as affected by extraction conditions. Food Hydrocoll. 24, 164-171 (2010). https://doi.org/10.1016/j.foodhyd.2009.09.001

25. Jridi, M., Nasri, R., Salem, R.B.S.B., Lassoued, I., Barkia, A., Nasri, M., Souissi, N.: Chemical and biophysical properties of gelatins extracted from the skin of octopus (Octopus vulgaris). LWT - Food Sci. Technol. 60, 881-889 (2015). https://doi.org/10.1016/j.lwt.2014.10.057

26. Arnesen, J.A., Gildberg, A.: Preparation and characterisation of gelatine from the skin of harp seal (Phoca groendlandica). Bioresour. Technol. 82, 191-194 (2002). https://doi.org/10.1016/S0960-8524(01)00164$\mathrm{X}$

27. Muyonga, J.H., Cole, C.G.B., Duodu, K.G.: Extraction and physico-chemical characterisation of Nile perch (Lates niloticus) skin and bone gelatin. Food Hydrocoll. 18, 581-592 (2004). https://doi.org/10.1016/j.foodhyd.2003.08.009

28. Karim, A.A., Bhat, R.: Fish gelatin: properties, challenges, and prospects as an alternative to mammalian gelatins. Food Hydrocoll. 23, 563-576 (2009). https://doi.org/10.1016/j.foodhyd.2008.07.002

29. Bkhairia, I., Mhamdi, S., Jridi, M., Nasri, M.: New acidic proteases from Liza aurata viscera: Characterization and application in gelatin production. Int. J. Biol. Macromol. 92, 533- 542 (2016). https://doi.org/10.1016/j.ijbiomac.2016.07.063

30. Binsi, P.K., Nayak, N., Sarkar, P.C., Joshy, C.G., Ninan, G., Ravishankar, C.N.: Gelation and thermal characteristics of microwave extracted fish gelatin-natural gum composite gels. J. Food Sci. Technol. 54, 518-530 (2017). https://doi.org/10.1007/s13197-017-2496-9

31. Nagarajan, M., Benjakul, S., Prodpran, T., Songtipy, P., Kishimura, H.: Characteristics and functional properties of gelatin from splendid squid (Loligo formosana) skin as affected by extraction temperatures. Food Hydrocoll. 29, 389-397 (2012). https://doi.org/10.1016/j.foodhyd.2012.04.001

32. Jamilah, B., Tan, K.W., Umi-Hartina, M.R., Azizah, A.: Gelatins from three cultured freshwater fish skins obtained by liming process. Food Hydrocoll. 25, 1256-1260 (2011).

https://doi.org/10.1016/j.foodhyd.2010.11.023

33. Avena-Bustillos, R., Olsen, C., Olson, D., Chiou, B., Yee, E., Bechtel, P., Mchugh, T.: Water vapor permeability of mammalian and fish gelatin films. J. Food Sci. 71, E202-E207 (2006). https://doi.org/10.1111/j.17503841.2006.00016.x

34. Zuniga, R.N., Aguilera, J.M.: Structure fracture relationships in gas-filled gelatin gels. Food Hydrocoll. 23, 1351-1357 (2009). https://doi.org/10.1016/j.foodhyd.2008.11.012

35. Ahmad, M., Benjakul, S.: Characteristics of gelatin from the skin of unicorn leatherjacket (Aluterus monoceros) as influenced by acid pre-treatment and extraction time. Food Hydrocoll. 25, 381-388 (2011). https://doi.org/10.1016/j.foodhyd.2010.07.004

36. Rawdkuen, S., Thitipramote, N., Benjakul, S.: Preparation and functional characterization of fish skin gelatin and comparison with commercial gelatin. Int. J. Food Sci. Technol. 48, 1093-1102 (2013). https://doi.org/10.1111/ijfs.12067

37. Wasswa, J., Tang, J., Gu, X.: Utilization of fish processing by products in the gelatin industry. Food Rev. Int. 23, 159-174 (2007). https://doi.org/10.1080/87559120701225029 
38. Kaewruang, P., Benjakul, S., Prodpran, T.: Effect of phosphorylation on gel properties of gelatin from the skin of unicorn leatherjacket. Food Hydrocoll. 35, 694-699 (2014).

https://doi.org/10.1016/j.foodhyd.2013.08.017

39. Ninan, G., Jose, J., Abubacker, Z.: Preparation and characterization of gelatin extracted from the skins of rohu (Labeo rohita) and common carp (Cyprinus carpio). J. Food Process. Preserv. 35, 143-162 (2011). https://doi.org/10.1111/j.1745-4549.2009.00467.x

\section{Tables}

Table 1. Experimental design for dehairing of bovine hides as a pre-treatment prior to gelatin extraction (locations of R1, R2, R3, R4 and R5 on each bovine hide are indicated in Fig. 1) and mean number of hairs (with standard error) on bovine hides after application of the dehairing treatments.

\begin{tabular}{|c|c|c|c|c|c|c|}
\hline \multirow{2}{*}{$\begin{array}{l}\text { Hide } \\
\text { Number }\end{array}$} & \multicolumn{6}{|c|}{ Dehairing treatment applied to bovine hide pieces prior to gelatin extraction } \\
\hline & $\begin{array}{l}\text { Control } \\
\text { (CT) }\end{array}$ & $\begin{array}{l}5 \% \\
\text { Acetic } \\
\text { Acid } \\
\text { (AA) }\end{array}$ & $\begin{array}{l}\text { Control plus } 5 \\
\% \text { acetic acid } \\
\text { (CTAA) }\end{array}$ & $\begin{array}{l}10 \% \\
\text { Calcium } \\
\text { hydroxide } \\
(\mathrm{CH})\end{array}$ & $\begin{array}{l}0.02 \% \\
\text { Keratinase } \\
\text { enzyme } \\
(\text { KTN) }\end{array}$ & $\begin{array}{l}2.5 \% \\
\text { Papain } \\
\text { enzyme } \\
\text { (PP) }\end{array}$ \\
\hline 1 & R1 & R3 & R1 & R2 & R5 & R4 \\
\hline 2 & R5 & R2 & R5 & R1 & R4 & R3 \\
\hline 3 & R4 & R1 & R4 & R5 & R3 & R2 \\
\hline 4 & R3 & R5 & R3 & R4 & R2 & R1 \\
\hline 5 & R2 & R4 & R2 & R3 & R1 & R5 \\
\hline $\begin{array}{l}\text { Number of hairs/ } \\
\mathrm{cm}^{2} \text { after } \\
\text { dehairing }^{1}\end{array}$ & $N D^{2}$ & $\begin{array}{l}22.6 \\
(8.03)\end{array}$ & ND & $23.2(8.03)$ & $17.8(8.03)$ & $3.6(8.03)$ \\
\hline
\end{tabular}

${ }^{1}$ Means (with standard error of the mean) for number of hairs. Analysis of variance indicated the probability of the $\mathrm{F}$ value was $\mathrm{P}=0.3118$.

${ }^{2} \mathrm{ND}$, not determined.

Table 2. Means (with standard errors of the mean) for gelatin yield and proximate composition of bovine hide gelatin extracted after application of different dehairing treatments. 


\begin{tabular}{|c|c|c|c|c|c|c|c|}
\hline \multicolumn{2}{|c|}{ Measurements } & \multicolumn{5}{|c|}{$\begin{array}{l}\text { Treatments applied to dehair bovine hides prior to gelatin } \\
\text { extraction }\end{array}$} & \multirow[t]{2}{*}{$P$ value } \\
\hline & & $\begin{array}{l}\text { Control } \\
\text { (CT) }\end{array}$ & $\begin{array}{l}5 \% \text { Acetic } \\
\text { Acid (AA) }\end{array}$ & $\begin{array}{l}\text { Control } \\
\text { plus } 5 \% \\
\text { acetic } \\
\text { acid } \\
\text { (CTAA) }\end{array}$ & $\begin{array}{l}10 \% \\
\text { Calcium } \\
\text { hydroxide } \\
(\mathrm{CH})\end{array}$ & $\begin{array}{l}0.02 \% \\
\text { Keratinase } \\
\text { enzyme } \\
(\text { KTN) }\end{array}$ & \\
\hline \multirow[t]{2}{*}{$\begin{array}{l}\text { Gelatin yield } \\
(\%)\end{array}$} & $\begin{array}{l}\text { Wet tissue } \\
\text { basis }\end{array}$ & $\begin{array}{l}3.40 \\
(1.22) \mathrm{c}\end{array}$ & $\begin{array}{l}10.16 \\
(1.22) b\end{array}$ & $\begin{array}{l}12.45 \\
(1.22) b\end{array}$ & $\begin{array}{l}4.86 \\
(1.22) \mathrm{c}\end{array}$ & $\begin{array}{l}17.65 \\
(1.22) \mathrm{a}\end{array}$ & $\begin{array}{l}<.0001 \\
0.01\end{array}$ \\
\hline & $\begin{array}{l}\text { Dry tissue } \\
\text { basis }\end{array}$ & $\begin{array}{l}11.37 \\
(5.35) b\end{array}$ & $\begin{array}{l}54.25 \\
(5.35) \text { a }\end{array}$ & $\begin{array}{l}45.07 \\
(5.35) \text { a }\end{array}$ & $\begin{array}{l}18.88 \\
(5.35) b\end{array}$ & $\begin{array}{l}55.02 \\
(5.35) \mathrm{a}\end{array}$ & $<.0001$ \\
\hline \multirow{4}{*}{$\begin{array}{l}\text { Proximate } \\
\text { composition } \\
\text { of gelatin } \\
(\%)\end{array}$} & $\begin{array}{l}\text { Crude } \\
\text { protein }\end{array}$ & $\begin{array}{l}98.39 \\
(1.02) \\
a b\end{array}$ & $\begin{array}{l}98.66 \\
(1.02) a b\end{array}$ & $\begin{array}{l}101.24 \\
(1.02) \mathrm{a}\end{array}$ & $\begin{array}{l}99.14 \\
(1.02) a b\end{array}$ & $\begin{array}{l}95.94 \\
(1.02) b\end{array}$ & 0.0279 \\
\hline & Crude fat & $\begin{array}{l}0.19 \\
(0.07) \\
a b\end{array}$ & $\begin{array}{l}0.014 \\
(0.07) b\end{array}$ & $\begin{array}{l}0.002 \\
(0.07) b\end{array}$ & $\begin{array}{l}0.02 \\
(0.07) b\end{array}$ & $\begin{array}{l}0.32 \\
(0.07) a\end{array}$ & 0.0324 \\
\hline & Ash & $\begin{array}{l}0.35 \\
(0.10) b\end{array}$ & $\begin{array}{l}0.026 \\
(0.10) \mathrm{c}\end{array}$ & $\begin{array}{l}0.00 \\
(0.10) c\end{array}$ & $\begin{array}{l}0.66 \\
(0.10) a\end{array}$ & $\begin{array}{l}0.22 \\
(0.10) b c\end{array}$ & 0.0005 \\
\hline & Moisture & $\begin{array}{l}3.82 \\
(0.95)\end{array}$ & $\begin{array}{l}4.31 \\
(0.95)\end{array}$ & $\begin{array}{l}2.99 \\
(0.95)\end{array}$ & $\begin{array}{l}4.23 \\
(0.95)\end{array}$ & $\begin{array}{l}7.06 \\
(0.95)\end{array}$ & 0.0683 \\
\hline \multicolumn{2}{|l|}{$\mathrm{pH}$} & $\begin{array}{l}6.29 \\
(0.25) b\end{array}$ & $\begin{array}{l}5.01(0.25) \\
\mathrm{C}\end{array}$ & $\begin{array}{l}4.86(0.25) \\
\mathrm{c}\end{array}$ & $\begin{array}{l}7.72(0.25) \\
a\end{array}$ & $\begin{array}{l}6.75(0.25) \\
b\end{array}$ & $<0.0001$ \\
\hline \multicolumn{2}{|c|}{ Transmittance (\%) } & $\begin{array}{l}23.78 \\
(3.94) \mathrm{c}\end{array}$ & $\begin{array}{l}91.40 \\
(3.94) \mathrm{a}\end{array}$ & $\begin{array}{l}91.74 \\
(3.94) \mathrm{a}\end{array}$ & $\begin{array}{l}66.36 \\
(3.94) \text { ab }\end{array}$ & $\begin{array}{l}55.12 \\
(3.94) \mathrm{b}\end{array}$ & 0.0001 \\
\hline \multirow[t]{3}{*}{ Gel color } & $L^{*}$ & $\begin{array}{l}40.36 \\
(1.54) \\
\text { bc }\end{array}$ & $\begin{array}{l}45.92 \\
(1.54) a\end{array}$ & $\begin{array}{l}47.48 \\
(1.54) \mathrm{a}\end{array}$ & $\begin{array}{l}44.33 \\
(1.54) \text { ab }\end{array}$ & $\begin{array}{l}39.55 \\
(1.54) \mathrm{c}\end{array}$ & 0.0057 \\
\hline & $a^{\star}$ & $\begin{array}{l}1.73 \\
(0.37) \\
a b\end{array}$ & $\begin{array}{l}0.57 \\
(0.37) \mathrm{c}\end{array}$ & $\begin{array}{l}0.97 \\
(0.37) b c\end{array}$ & $\begin{array}{l}2.05 \\
(0.37) a b\end{array}$ & $\begin{array}{l}2.19 \\
(0.37) \mathrm{a}\end{array}$ & 0.0267 \\
\hline & $b^{*}$ & $\begin{array}{l}4.07 \\
(0.69) \mathrm{c}\end{array}$ & $\begin{array}{l}12.15 \\
(0.69) \mathrm{a}\end{array}$ & $\begin{array}{l}12.40 \\
(0.69) \text { a }\end{array}$ & $\begin{array}{l}9.83 \\
(0.69) b\end{array}$ & $\begin{array}{l}4.61 \\
(0.69) \mathrm{c}\end{array}$ & $\begin{array}{l}< \\
0.0001\end{array}$ \\
\hline \multicolumn{2}{|c|}{ Gel strength (g) } & $\begin{array}{l}201.09 \\
(29.31) \\
b\end{array}$ & $\begin{array}{l}300.08 \\
(26.21) a\end{array}$ & $\begin{array}{l}235.28 \\
(26.21) a b\end{array}$ & $\begin{array}{l}172.96 \\
(26.21) b\end{array}$ & $\begin{array}{l}74.31 \\
(29.31) \mathrm{c}\end{array}$ & 0.0004 \\
\hline \multirow[t]{3}{*}{$\begin{array}{l}\text { Rheological } \\
\text { properties }\end{array}$} & $\begin{array}{l}\text { Gelling } \\
\text { temperature } \\
\left({ }^{\circ} \mathrm{C}\right)\end{array}$ & $\begin{array}{l}21.31 \\
(2.40)\end{array}$ & $\begin{array}{l}20.21 \\
(2.14)\end{array}$ & $\begin{array}{l}20.48 \\
(2.14)\end{array}$ & $\begin{array}{l}20.74 \\
(2.14)\end{array}$ & $\begin{array}{l}16.60 \\
(2.40)\end{array}$ & 0.656 \\
\hline & $\begin{array}{l}\text { Melting } \\
\text { temperature } \\
\left({ }^{\circ} \mathrm{C}\right)\end{array}$ & $\begin{array}{l}31.52 \\
(2.19)\end{array}$ & $\begin{array}{l}29.57 \\
(1.94)\end{array}$ & $\begin{array}{l}30.51 \\
(1.94)\end{array}$ & $\begin{array}{l}29.31 \\
(1.96)\end{array}$ & $\begin{array}{l}25.81 \\
(2.19)\end{array}$ & 0.4396 \\
\hline & $\begin{array}{l}\text { Storage } \\
\text { modulus } \\
(\mathrm{G} \otimes, \mathrm{pa})\end{array}$ & $\begin{array}{l}1353.25 \\
(387.88)\end{array}$ & $\begin{array}{l}1889.00 \\
(346.93)\end{array}$ & $\begin{array}{l}1438.00 \\
(346.93)\end{array}$ & $\begin{array}{l}1488.24 \\
(346.93)\end{array}$ & $\begin{array}{l}441.39 \\
(387.88)\end{array}$ & 0.1331 \\
\hline
\end{tabular}




$\begin{array}{lllllll}\text { Loss } & 25.53 & 27.69 & 18.63 & 25.69 & 13.68 & 0.2799 \\ \text { modulus } & (5.24) & (4.69) & (4.69) & (4.69) & (5.24) & \\ (\mathrm{G} \rrbracket, \mathrm{pa}) & & & & & & \end{array}$

a, b, c Means in the same row with different letters are significantly different $(P<0.05)$ according to least squares means differences.

Table 3. Mean amino acids (\% mol) composition of gelatin extracted from bovine hide after application of different treatments for dehairing

\begin{tabular}{|c|c|c|c|c|c|c|c|}
\hline \multirow{2}{*}{$\begin{array}{l}\text { Amino acids } \\
\text { (\% mole) }\end{array}$} & \multicolumn{5}{|c|}{ Treatments applied to dehair bovine hides prior to gelatin extraction } & \multirow[t]{2}{*}{$\mathrm{SE}^{1}$} & \multirow[t]{2}{*}{$P$ value } \\
\hline & $\begin{array}{l}\text { Control } \\
\text { (CT) }\end{array}$ & $\begin{array}{l}5 \% \\
\text { Acetic } \\
\text { Acid } \\
(\mathrm{AA})\end{array}$ & $\begin{array}{l}\text { Control plus } \\
5 \% \text { acetic } \\
\text { acid (CTAA) }\end{array}$ & $\begin{array}{l}10 \% \\
\text { Calcium } \\
\text { hydroxide } \\
(\mathrm{CH})\end{array}$ & $\begin{array}{l}0.02 \% \\
\text { Keratinase } \\
\text { enzyme } \\
(\text { KTN) }\end{array}$ & & \\
\hline Alanine & 10.55 & 10.62 & 10.61 & 10.26 & 10.30 & 0.19 & 0.5200 \\
\hline Arginine & 5.37 & 5.36 & 5.49 & 5.56 & 5.45 & 0.07 & 0.2900 \\
\hline Aspartic acid & $4.69 \mathrm{a}$ & $4.22 \mathrm{ab}$ & $3.79 \mathrm{bc}$ & $3.35 \mathrm{c}$ & $3.53 \mathrm{bc}$ & 0.26 & 0.0109 \\
\hline Glutamic acid & 7.54 & 7.22 & 6.96 & 6.96 & 7.52 & 0.2 & 0.1453 \\
\hline Glycine & $31.4 b$ & $32.5 \mathrm{a}$ & $33.5 \mathrm{a}$ & $33.14 \mathrm{a}$ & $32.70 \mathrm{a}$ & 0.31 & 0.0017 \\
\hline Histidine & 0.58 & 0.60 & 0.81 & 0.85 & 0.77 & 0.13 & 0.5200 \\
\hline Hydroxyproline & 9.89 & 10.43 & 10.55 & 10.55 & 10.37 & 0.19 & 0.1362 \\
\hline Isoleucine & 1.29 & 1.22 & 1.26 & 1.27 & 1.31 & 0.02 & 0.2152 \\
\hline Leucine & $2.77 \mathrm{a}$ & $2.54 \mathrm{~b}$ & $2.42 \mathrm{c}$ & $2.59 \mathrm{~b}$ & $2.61 \mathrm{~b}$ & 0.03 & $<0.0001$ \\
\hline Lysine & 2.84 & 2.67 & 2.66 & 2.62 & 2.75 & 0.07 & 0.2819 \\
\hline Methionine & $\begin{array}{l}0.60 \\
a b\end{array}$ & $0.54 \mathrm{~b}$ & $0.56 a b$ & $0.63 \mathrm{a}$ & $0.55 b$ & 0.02 & 0.0402 \\
\hline Phenylalanine & $1.41 \mathrm{a}$ & $1.37 \mathrm{ab}$ & $1.23 \mathrm{c}$ & $1.39 a b$ & $1.26 \mathrm{bc}$ & 0.04 & 0.0182 \\
\hline Proline & 12.30 & 12.49 & 12.52 & 12.37 & 12.30 & 0.11 & 0.5600 \\
\hline Serine & $\begin{array}{l}3.71 \\
a b\end{array}$ & $3.63 a b$ & $3.57 b$ & $3.57 b$ & $3.76 \mathrm{a}$ & 0.04 & 0.0380 \\
\hline Threonine & 2.13 & 1.86 & 1.93 & 2.00 & 2.01 & 0.07 & 0.1800 \\
\hline Tyrosine & 0.50 & 0.40 & 0.32 & 0.57 & 0.52 & 0.06 & 0.1049 \\
\hline Valine & 2.36 & 2.28 & 1.76 & 2.24 & 2.22 & 0.17 & 0.1730 \\
\hline
\end{tabular}

${ }^{1} \mathrm{SE}=$ Standard Error 
a, b, c Means in the same row with different letters are significantly different $(P<0.05)$ according to least squares means differences.

Table 4. Thermal denaturation properties (means with standard errors of the means in parentheses) of $\mathrm{BH}$ gelatin extracted after the various dehairing treatments as measured by differential scanning calorimetry

\begin{tabular}{|c|c|c|c|c|c|c|}
\hline \multirow[t]{2}{*}{ Measurements } & \multicolumn{6}{|c|}{ Treatments applied to dehair bovine hides prior to gelatin extraction } \\
\hline & $\begin{array}{l}\text { Control } \\
\text { (CT) }\end{array}$ & $\begin{array}{l}5 \% \\
\text { Acetic } \\
\text { Acid } \\
(A A)\end{array}$ & $\begin{array}{l}\text { Control plus } 5 \\
\% \text { acetic acid } \\
\text { (CTAA) }\end{array}$ & $\begin{array}{l}10 \% \text { Calcium } \\
\text { hydroxide } \\
(\mathrm{CH})\end{array}$ & $\begin{array}{l}0.02 \% \\
\text { Keratinase } \\
\text { enzyme (KTN) }\end{array}$ & $\begin{array}{l}P \\
\text { value }\end{array}$ \\
\hline $\begin{array}{l}\text { Denaturation } \\
\text { onset } \\
\text { temperature }\left({ }^{\circ} \mathrm{C}\right)\end{array}$ & $\begin{array}{l}27.69 \\
(.78) \mathrm{a}\end{array}$ & $\begin{array}{l}25.64 \\
(0.70) \\
a b\end{array}$ & $25.86(0.70) a b$ & $\begin{array}{l}24.75(0.70) \\
b\end{array}$ & $23.50(0.78) b$ & 0.0189 \\
\hline $\begin{array}{l}\text { Denaturation } \\
\text { peak temperature } \\
\left({ }^{\circ} \mathrm{C}\right)\end{array}$ & $\begin{array}{l}33.14 \\
(1.01)\end{array}$ & $\begin{array}{l}32.19 \\
(0.90)\end{array}$ & $31.94(0.90)$ & $31.66(0.90)$ & $30.20(1.01)$ & 0.3817 \\
\hline $\begin{array}{l}\text { Denaturation end } \\
\text { temperature }\left({ }^{\circ} \mathrm{C}\right)\end{array}$ & $\begin{array}{l}40.29 \\
(1.09)\end{array}$ & $\begin{array}{l}39.64 \\
(0.97)\end{array}$ & $39.16(0.97)$ & $38.33(0.97)$ & $39.20(1.09)$ & 0.7427 \\
\hline $\begin{array}{l}\text { Enthalpy } \\
(\mathrm{kJ} / \mathrm{mol})\end{array}$ & $\begin{array}{l}1046 \\
(101) \\
a b c\end{array}$ & $\begin{array}{l}1319 \\
(90) \mathrm{a}\end{array}$ & $1230(90) a b$ & $949(90) \mathrm{bc}$ & $837(101) \mathrm{c}$ & 0.0110 \\
\hline
\end{tabular}

a, b, c Means in the same row with different letters are significantly different $(P<0.05)$ according to least squares means differences.

Table 5. Foaming, emulsifying, water holding and fat binding capacities (means with standard error of the mean in parentheses) of gelatin extracted from bovine hides dehaired using different treatments 
Measurements $\begin{aligned} & \text { Treatments } \\ & \text { extraction }\end{aligned}$

$\begin{array}{lllll}\text { Control } & 5 \% & \text { Control } & 10 \% & 0.02 \% \\ \text { (CT) } & \text { Acetic } & \text { plus } 5 \% & \text { Calcium } & \text { Keratinase } \\ & \text { Acid } & \text { acetic acid } & \text { hydroxide } & \text { enzyme } \\ & \text { (AA) } & \text { (CTAA) } & \text { (CH) } & \text { (KTN) }\end{array}$

\section{Foam expansion (FE)}

\begin{tabular}{lccccccc|}
$\begin{array}{l}\text { At } 0.5 \% \\
\text { concentration }\end{array}$ & 32.80 & 30.00 & 32.00 & 34.00 & 26.00 & 3.38 & 0.5082 \\
\hline $\begin{array}{l}\text { At } 1 \% \\
\text { concentration }\end{array}$ & 40.40 & 40.80 & 42.80 & 45.20 & 34.80 & 4.45 & 0.5692 \\
\hline $\begin{array}{l}\text { At 2 \% } \\
\text { concentration }\end{array}$ & 44.80 & 39.60 & 51.60 & 51.20 & 40.00 & 5.78 & 0.4253 \\
\hline
\end{tabular}

Foam stability (FS)

\begin{tabular}{|c|c|c|c|c|c|c|c|}
\hline $\begin{array}{l}\text { At } 0.5 \% \\
\text { concentration } \\
\text { for } 30 \text { min }\end{array}$ & 29.20 & 19.40 & 25.20 & 20.80 & 18.40 & 4.43 & 0.4207 \\
\hline
\end{tabular}

\begin{tabular}{|c|c|c|c|c|c|c|c|}
\hline $\begin{array}{l}\text { At } 1 \% \\
\text { concentration } \\
\text { for } 30 \mathrm{~min}\end{array}$ & 38.80 & 22.00 & 30.00 & 24.40 & 25.60 & 5.33 & 0.2298 \\
\hline
\end{tabular}

\begin{tabular}{lccccccc}
$\begin{array}{l}\text { At } 2 \% \\
\text { concentration } \\
\text { for } 30 \text { min }\end{array}$ & 42.40 & 19.60 & 38.40 & 27.60 & 29.60 & 6.58 & 0.1524 \\
$\begin{array}{l}\text { At } 0.5 \% \\
\text { concentration } \\
\text { for } 60 \text { min }\end{array}$ & 27.20 & 14.40 & 20.40 & 18.40 & 16.80 & 4.33 & 0.3180 \\
$\begin{array}{l}\text { At } 1 \% \\
\text { concentration } \\
\text { for } 60 \text { min }\end{array}$ & 37.20 & 16.00 & 23.60 & 20.00 & 23.20 & 5.41 & 0.1090 \\
$\begin{array}{l}\text { At } 2 \% \\
\text { concentration } \\
\text { for } 60 \text { min }\end{array}$ & 40.00 & 12.80 & 25.60 & 25.60 & 25.60 & 6.81 & 0.1396 \\
\hline
\end{tabular}

\section{Emulsion stability index $\left(E S I, \mathrm{~m}^{2} / \mathrm{g}\right)$}

\begin{tabular}{|c|c|c|c|c|c|c|c|}
\hline $\begin{array}{l}\text { At } 0.5 \% \\
\text { concentration }\end{array}$ & 56.80 & 55.60 & 51.80 & 41.00 & 38.40 & 6.82 & 0.2276 \\
\hline $\begin{array}{l}\text { At } 1 \% \\
\text { concentration }\end{array}$ & $\begin{array}{l}54.20 \\
a b\end{array}$ & $\begin{array}{l}47.60 \\
a b\end{array}$ & $67.80 \mathrm{a}$ & $51.20 \mathrm{ab}$ & $34.00 \mathrm{~b}$ & 6.78 & 0.0341 \\
\hline $\begin{array}{l}\text { At } 2 \% \\
\text { concentration }\end{array}$ & $47.20 \mathrm{c}$ & $92.60 \mathrm{a}$ & $66.20 \mathrm{~b}$ & $40.00 \mathrm{c}$ & $34.00 \mathrm{c}$ & 4.48 & $<0.0001$ \\
\hline
\end{tabular}

\section{Emulsion activity index (EAl, minutes)}

$\begin{array}{llllllll}\begin{array}{l}\text { At } 0.5 \% \\ \text { concentration }\end{array} & 9.03 \mathrm{~b} & 18.30 \mathrm{a} & 19.43 \mathrm{a} & 18.68 \mathrm{a} & 18.32 \mathrm{a} & 1.69 & 0.0016\end{array}$




\begin{tabular}{|llllllll|}
\hline $\begin{array}{l}\text { At } 1 \% \\
\text { concentration }\end{array}$ & $6.20 \mathrm{~b}$ & $9.42 \mathrm{a}$ & $10.08 \mathrm{a}$ & $8.90 \mathrm{a}$ & $9.89 \mathrm{a}$ & 0.78 & 0.0146 \\
\hline $\begin{array}{l}\text { At 2 \% } \\
\text { concentration }\end{array}$ & 3.16 & 3.66 & 4.62 & 4.98 & 4.31 & 0.44 & 0.0602 \\
\hline $\begin{array}{l}\text { Water holding } \\
\text { capacity (\%) }\end{array}$ & $\begin{array}{l}1176.0 \\
\mathrm{C}\end{array}$ & $\begin{array}{l}3439.4 \\
\mathrm{a}\end{array}$ & $2709.8 \mathrm{~b}$ & $792.4 \mathrm{~cd}$ & $451.2 \mathrm{~d}$ & 233.6 & $<0.0001$ \\
\hline $\begin{array}{l}\text { Fat holding } \\
\text { capacity (\%) }\end{array}$ & $\begin{array}{l}5061.00 \\
\mathrm{a}\end{array}$ & $\begin{array}{l}3833.60 \\
\mathrm{~b}\end{array}$ & $2871.40 \mathrm{~b}$ & $3052.20 \mathrm{~b}$ & $2813.00 \mathrm{~b}$ & 382.31 & 0.0021 \\
\hline
\end{tabular}

a, b, c Means in the same row with different letters are significantly different $(P<0.05)$ according to least squares means differences.

Table 6. The wavenumbers of ATR-FTIR spectra peaks of gelatin extracted from bovine hides dehaired using different treatment

\begin{tabular}{|c|c|c|c|c|c|}
\hline \multirow[t]{2}{*}{ Measurements } & \multicolumn{5}{|c|}{ Wavenumbers $\left(\mathrm{cm}^{-1}\right)$ [Range from to] } \\
\hline & $\begin{array}{l}\text { Control } \\
\text { (CT) }\end{array}$ & $\begin{array}{l}5 \% \text { Acetic } \\
\text { Acid (AA) }\end{array}$ & $\begin{array}{l}\text { Control plus } 5 \% \\
\text { acetic acid (CTAA) }\end{array}$ & $\begin{array}{l}10 \% \text { Calcium } \\
\text { hydroxide }(\mathrm{CH})\end{array}$ & $\begin{array}{l}0.02 \% \text { Keratinase } \\
\text { enzyme (KTN) }\end{array}$ \\
\hline Amide I & $\begin{array}{l}1632- \\
1633\end{array}$ & $\begin{array}{l}1631- \\
1632\end{array}$ & $1631-1633$ & $1631-1632$ & 1632 \\
\hline Amide II & $\begin{array}{l}1521- \\
1537\end{array}$ & $\begin{array}{l}1532- \\
1533\end{array}$ & $1528-1531$ & $1525-1529$ & $1530-1532$ \\
\hline Amide III & $\begin{array}{l}1230- \\
1233\end{array}$ & $\begin{array}{l}1232- \\
1233\end{array}$ & $1232-1233$ & $1232-1235$ & 1233 \\
\hline Amide A & $\begin{array}{l}3289- \\
3295\end{array}$ & $\begin{array}{l}3297- \\
3298\end{array}$ & $3299-3300$ & $3290-3295$ & $3294-3297$ \\
\hline Amide B & $\begin{array}{l}2933- \\
2935\end{array}$ & $\begin{array}{l}2935- \\
2936\end{array}$ & 2937-2938 & $2922-2928$ & 2927-2929 \\
\hline
\end{tabular}

\section{Figures}




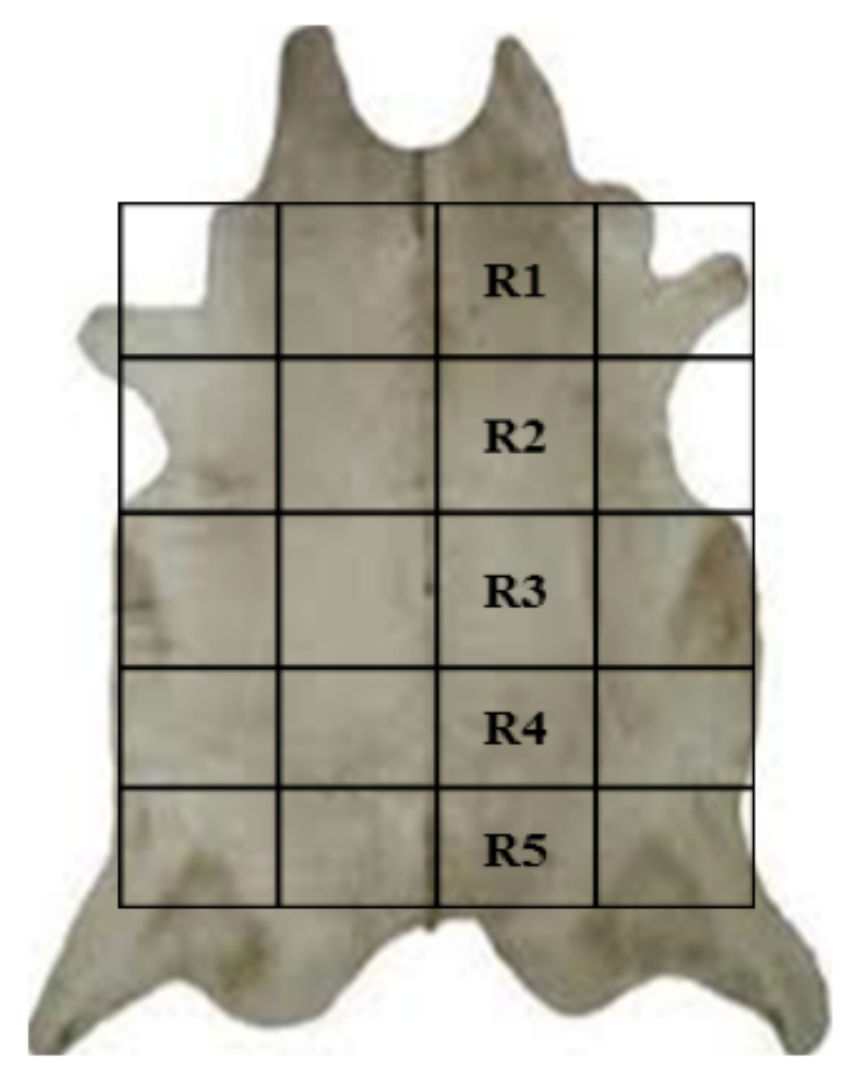

\section{Figure 1}

Locations on bovine hides (R1, R2, R3, R4 and R5) in which different chemicals were used as pre-treatment for dehairing and subsequently gelatin extraction 

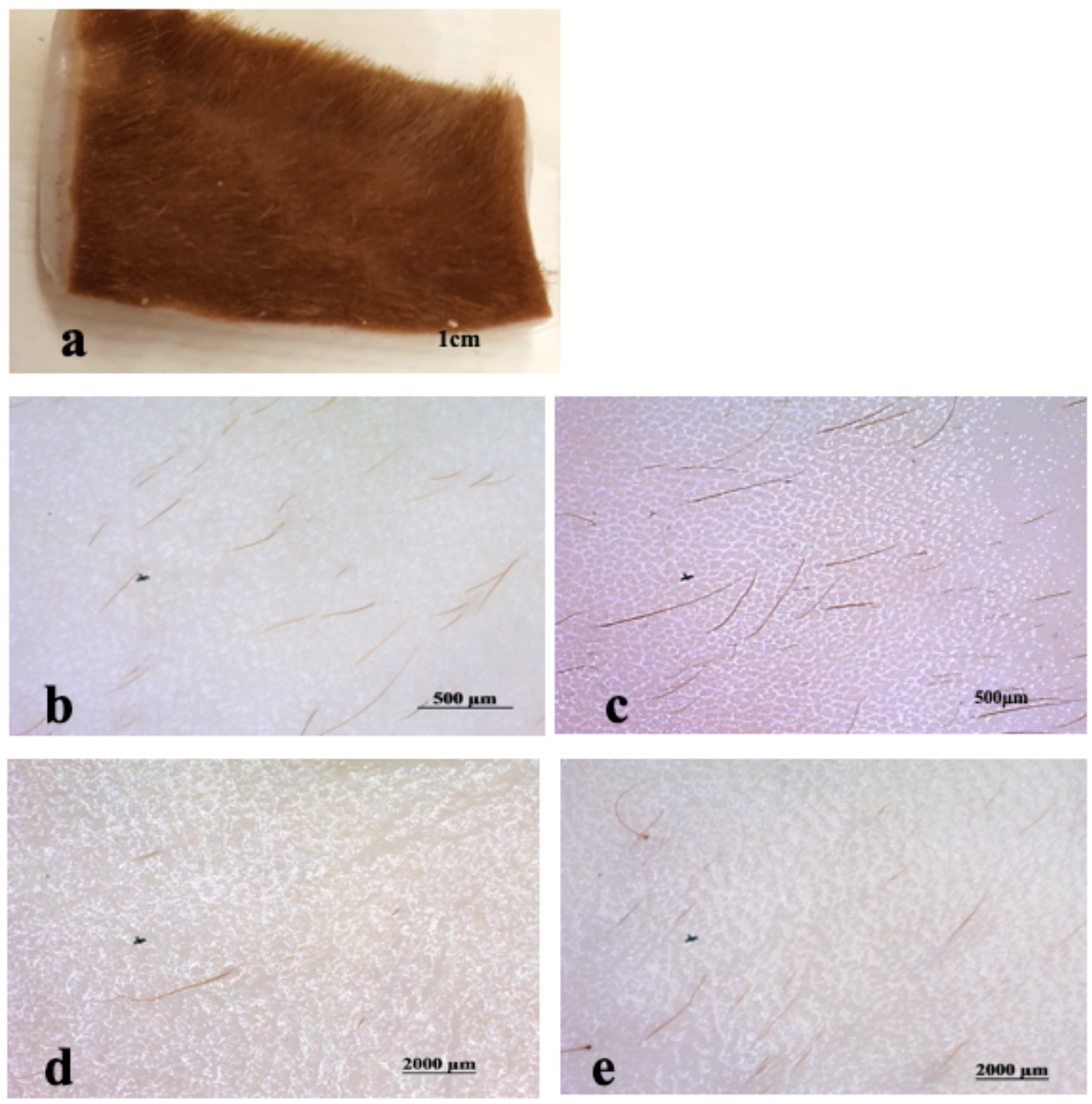

\section{Figure 2}

Dehaired bovine hides with different treatments. a; control/ control plus 5\% acetic acid (CT/ CTAA), b; 10\% calcium hydroxide (CH), c; 5\% acetic acid (AA), d; papain enzyme (PP) and e; 0.02\% keratinase enzyme (KTN) 


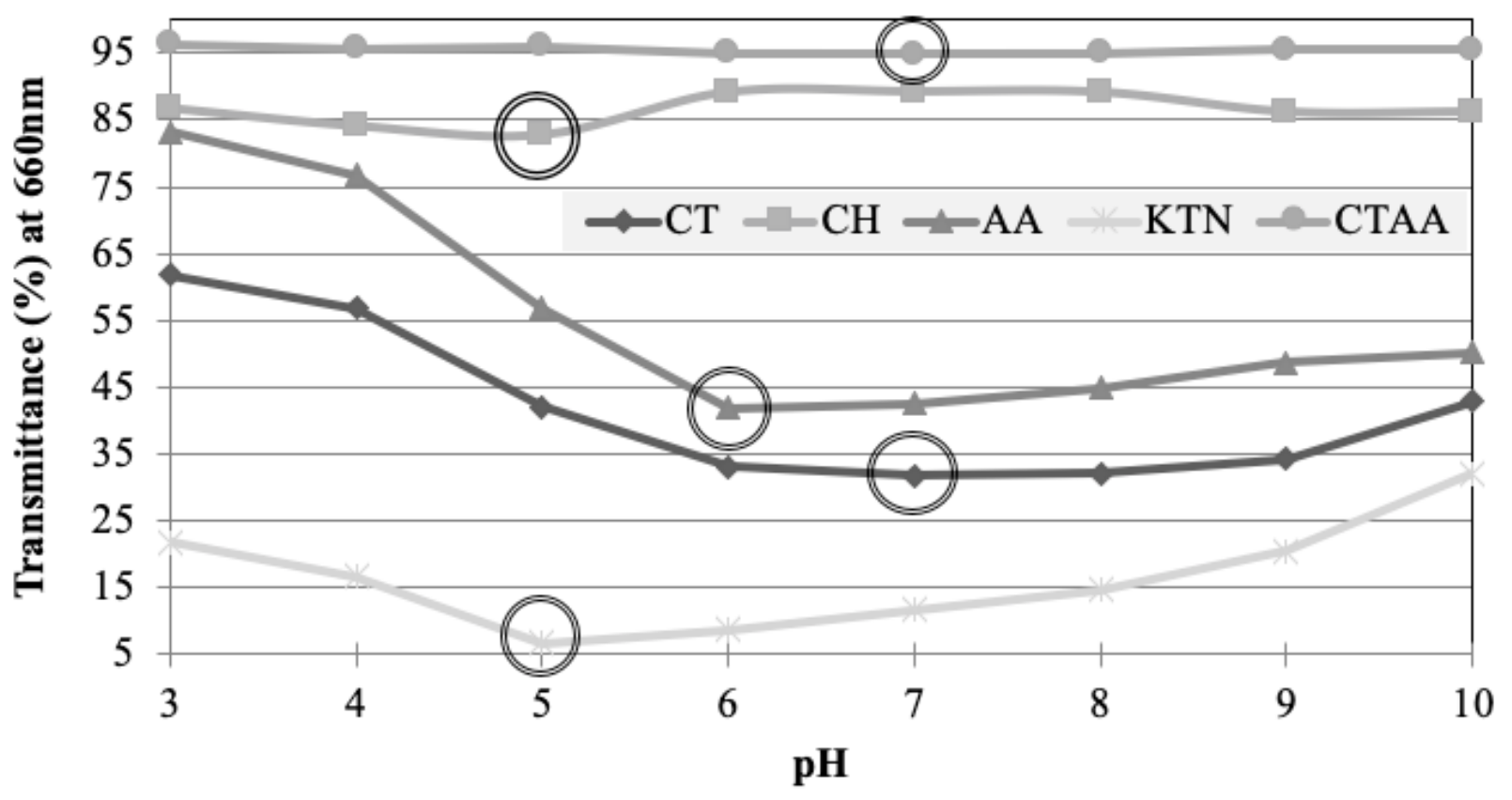

\section{Figure 3}

Isoelectric point of gelatin extracted from bovine hides. $\mathrm{pH}$ at Lowest transmittance indicate isoelectric point (double lined compound circles). Control (CT); $10 \%$ calcium hydroxide (CH); $5 \%$ acetic acid (AA); $0.02 \%$ keratinase enzyme (KTN) and control plus $5 \%$ acetic acid (CTAA).

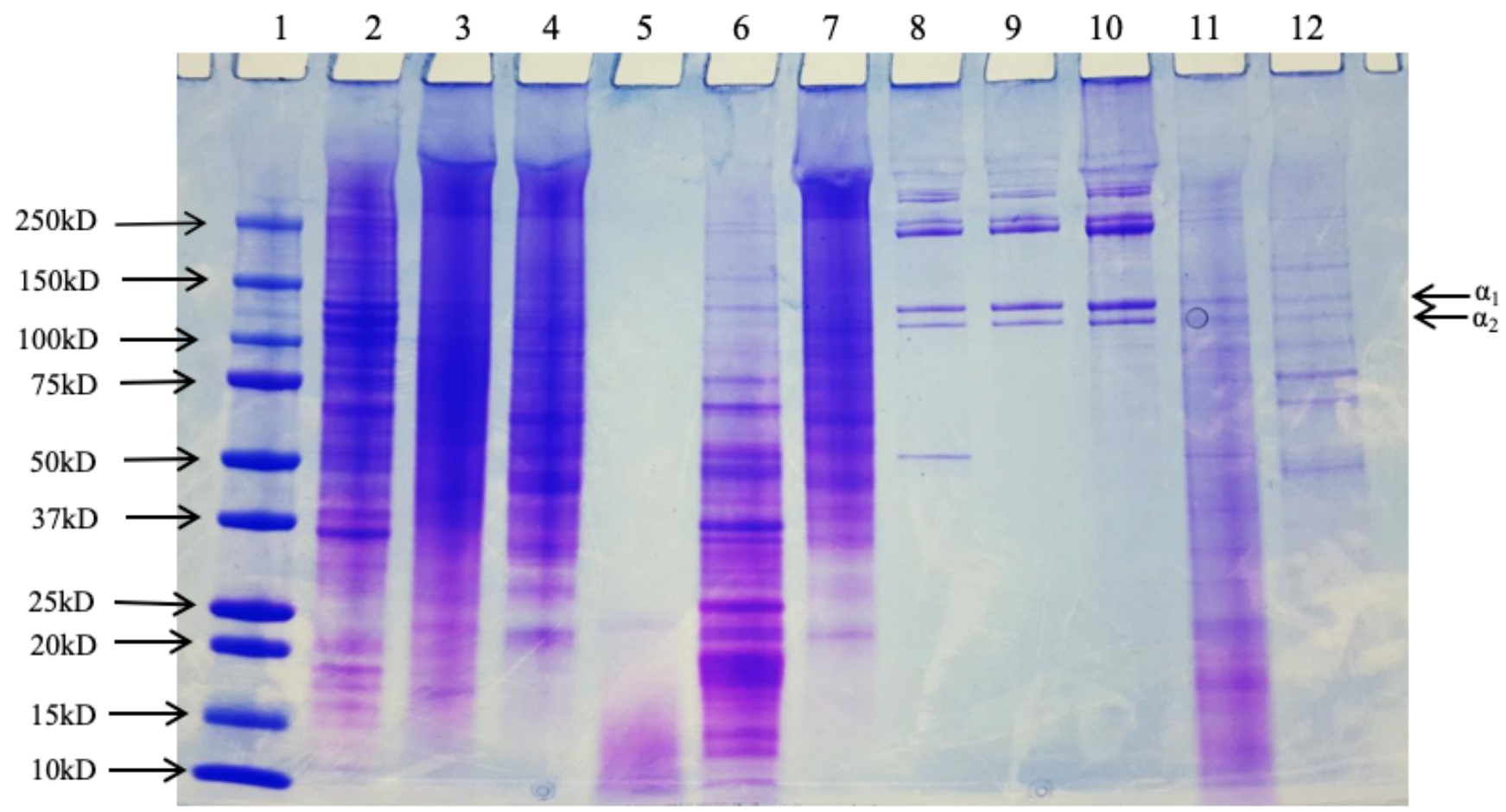

Figure 4 
SDS-PAGE pattern of Bovine hides gelatin and Bovine hides. Lane 1: Standard; Protein concentration was 5 mg/ml; Lane 2: (CT) control; Gelatin, Lane 3: (CH) 10\% calcium hydroxide; gelatin, Lane 4: (AA) 5\% acetic acid; gelatin, Lane 5: (PP) papain; Gelatin, Lane 6: (KTN) 0.02\% keratinase; gelatin, Lane 7: (CTAA) control plus 5\% acetic acid; gelatin, Lane 8: (CT) control; hides, Lane 9: (CH) 10\% calcium hydroxide; hides, Lane 10: (AA) acetic acid; hides, Lane 11: (PP) papain; hides, Lane 12: (KTN) keratinase; hides, and $12 \mu$ l of each sample was loaded.

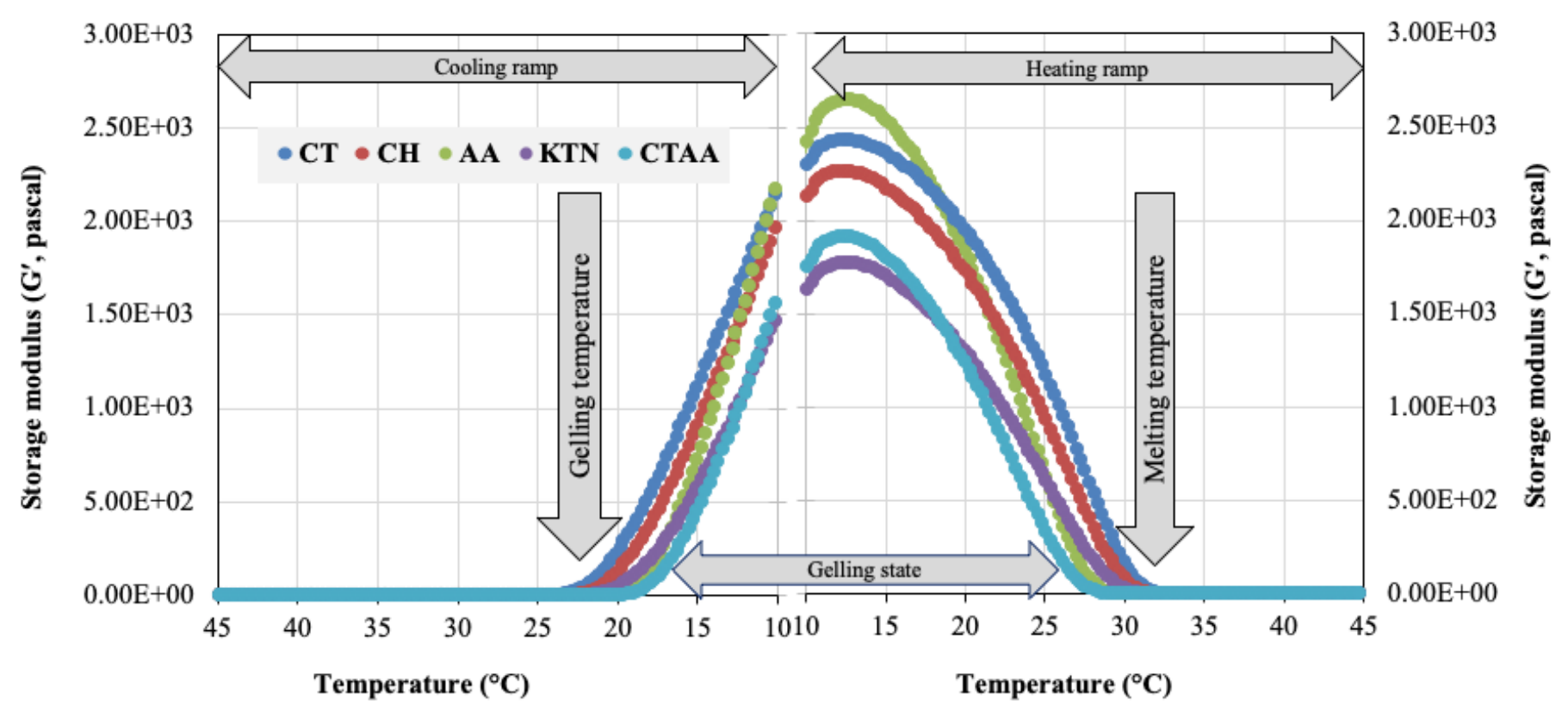

\section{Figure 5}

Temperature sweep curve of gelatin gel extracted from Bovine hides in different treatments. Control (CT); $10 \%$ calcium hydroxide (CH); $5 \%$ acetic acid (AA); $0.02 \%$ keratinase enzyme (KTN) and control plus $5 \%$ acetic acid (CTAA). 


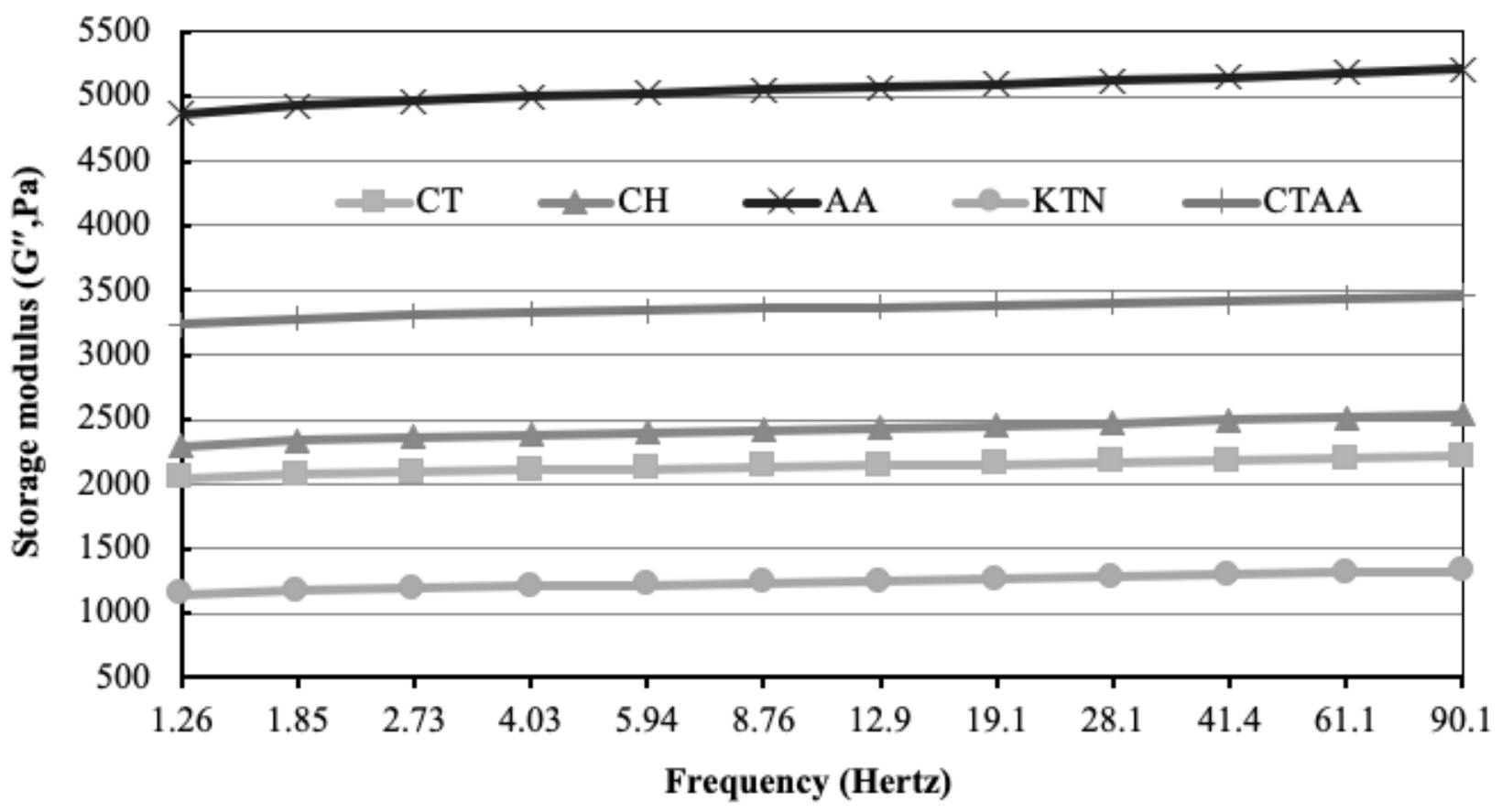

\section{Figure 6}

Frequency sweep curves for the frequency dependence of storage modulus (G区) of gelatin gel (6.67\%) extracted from Bovine hides in different treatments. Control (CT); $10 \%$ calcium hydroxide (CH); $5 \%$ acetic acid (AA); $0.02 \%$ keratinase enzyme (KTN) and control plus $5 \%$ acetic acid (CTAA). 


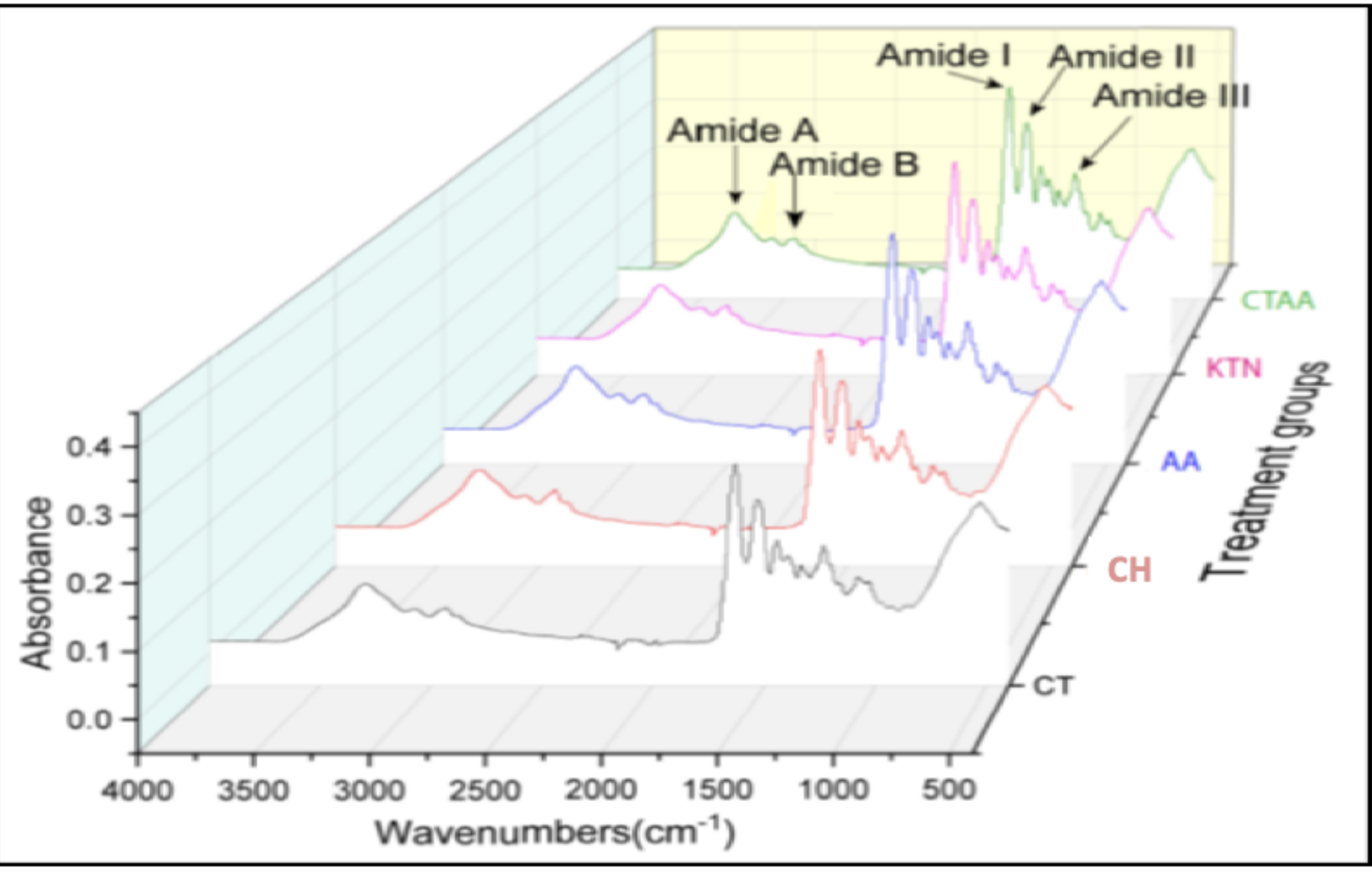

Figure 7

The ATR-FTIR spectra of gelatin extracted from bovine hides in different treatment groups. Control (CT); $10 \%$ calcium hydroxide (CH); $5 \%$ acetic acid (AA); $0.02 \%$ keratinase enzyme (KTN) and control plus $5 \%$ acetic acid (CTAA).

\section{Supplementary Files}

This is a list of supplementary files associated with this preprint. Click to download.

- GraphicalAbstract.png 